\title{
A Review of DNA Vaccines Against Influenza
}

\begin{abstract}
Leo Yi Yang Lee, Leonard Izzard and Aeron C. Hurt*
World Health Organisation Collaborating Centre for Reference and Research on Influenza at the Peter Doherty Institute, Melbourne, VIC, Australia
\end{abstract}

The challenges of effective vaccination against influenza are gaining more mainstream attention, as recent influenza seasons have reported low efficacy in annual vaccination programs worldwide. Combined with the potential emergence of novel influenza viruses resulting in a pandemic, the need for effective alternatives to egg-produced conventional vaccines has been made increasingly clear. DNA vaccines against influenza have been in development since the 1990s, but the initial excitement over success in murine model trials has been tempered by comparatively poor performance in larger animal models. In the intervening years, much progress has been made to refine the DNA vaccine platform - the rational design of antigens and expression vectors, the development of novel vaccine adjuvants, and the employment of innovative gene delivery methods. This review discusses how these advances have been applied in recent efforts to develop an effective influenza DNA vaccine.

Keywords: DNA vaccine, influenza, adjuvant, hemagglutinin, immunization

\section{INTRODUCTION}

Seasonal influenza epidemics continue to challenge public health systems worldwide, causing 3-5 million cases of severe respiratory disease and 290-650 thousand deaths annually (1). Despite annual updates to the seasonal vaccine, in 2017 overall vaccine effectiveness for Australia was estimated to be only 33\% (2), and interim estimates from the United States were similarly low for the 2017-2018 influenza seasons (36\%) (3). In addition, current seasonal vaccines provide little or no protection against novel pandemic viruses of animal origin (4). Consequently, research efforts have increased to improve seasonal vaccines and develop new vaccine platforms to achieve better protection against both seasonal and potentially pandemic influenza A viruses.

DNA vaccines possess numerous properties ideal for influenza control and have been trialled for a range of diseases, including viral and bacterial infections, and some cancers (5-7). Whilst inactivated influenza vaccines (IIVs) largely rely on antibody production to achieve effective protection (8), DNA vaccines can efficiently engage both humoral and cell-mediated immune responses (9). Their production does not require the growth of live virus and can be rapidly upscaled in response to emerging pandemic influenza $(10,11)$. Despite these advantages, promising immunogenic responses achieved in small animal models, predominantly mice, are rarely replicated in larger animals $(12,13)$. Murine model data are based on immune responses in highly inbred animals to mouse-adapted influenza viruses-an unreliable comparison to vaccination in the outbred human population against circulating influenza viruses $(14,15)$. Larger animal models susceptible to human influenza virus provide more relevant data-ferrets exhibit clinical signs, lung pathology, and transmission similar to humans $(16,17)$, whist human-like immune responses to influenza in cynomolgus macaques are good predictors of vaccine efficacy in humans $(15,18)$. As such, achieving sufficient 
immunogenicity in larger animals has required the development of potent delivery systems and adjuvants $(19,20)$. This review summarises innovations in the design, formulation, and delivery of DNA vaccines against influenza, and the major obstacles impeding their implementation (Figure 1).

\section{INFLUENZA VACCINES: PRODUCTION AND MECHANISMS OF PROTECTION}

Inactivated influenza vaccines and live attenuated influenza vaccines (LAIV) are the most widely used forms of influenza vaccine, and are generated by harvesting viruses grown in embryonated hen's eggs (21). The delivery of viral antigens derived from this process induces the production of antigen-specific antibodies, particularly against the haemagglutinin (HA) surface glycoprotein, to protect against future infections (22). However, egg-based vaccine production is time-consuming and resource-intensive, and manufacturing delays have previously caused severe vaccine shortages $(23,24)$. The overall vaccine effectiveness against seasonal influenza ranges from 40 to $60 \%$ during typical seasons, but is significantly reduced when antigenic mismatch occurs $(25,26)$. Furthermore, antigenic mismatch can be exacerbated by mutations which allow vaccine viruses to grow in eggs, which may also alter antigenic sites (27).

DNA vaccines are able to avoid many issues associated with egg-based vaccine production by generating viral proteins within host cells. To create a DNA vaccine, an antigen-encoding gene is cloned into a non-replicative expression plasmid, which is delivered to the host by traditional vaccination routes (28). Host cells which take up the plasmid express the vaccine antigen which can be presented to immune cells via the major histocompatibility complex (MHC) pathways. CD4+ T helper cell activation following MHC class II presentation of secreted DNA vaccine protein is critical for the production of antigen-specific antibodies (29),

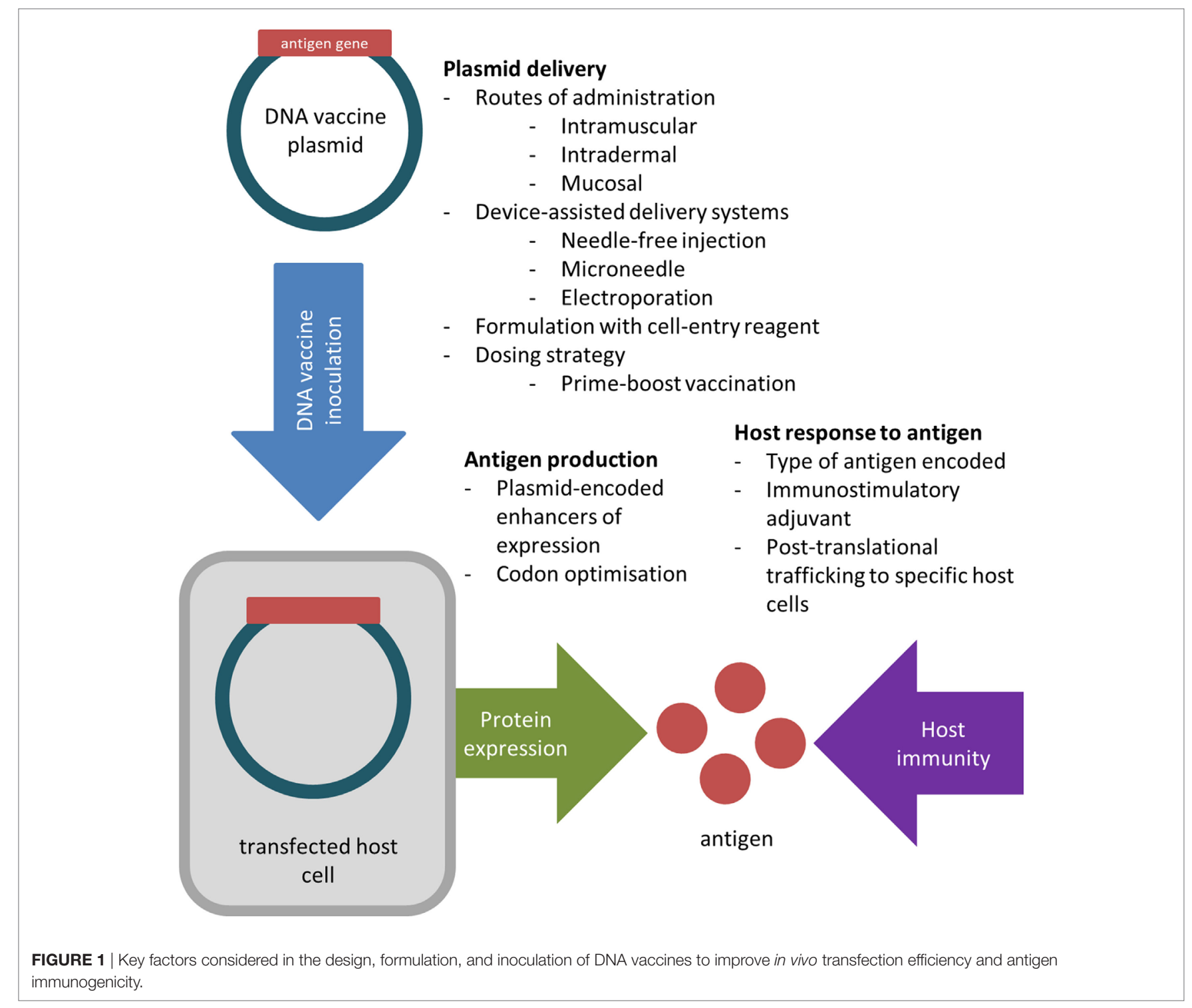


whist CD8+ T cell immunity, important for viral clearance, is predominantly activated by endogenously expressed antigens presented on MHC class I molecules (30).

\section{DESIGNING ANTIGENS FOR INFLUENZA DNA VACCINES}

The protection conferred by conventional IIV is based on the induction of HA-specific serum antibodies, which interfere with virus attachment to inhibit cell entry and limit infection $(8,31)$. Early mouse studies using DNA vaccines encoding H1 HA genes reported that protection against lethal homologous challenge correlated with increasing titres of HA-specific serum antibody $(32,33)$. As observed in LAIV, other correlates of immunity are less well defined, but the induction of local inflammation and cytotoxic $\mathrm{T}$ cell responses have been implicated as key mechanisms to enhance vaccine cross-reactivity and reduce the severity of infections $(34,35)$. As such, the nature of the host response to influenza DNA vaccination can be manipulated by the encoded antigen.

"Universal" influenza vaccines are being developed to induce broadly protective responses against drifted variant viruses and animal-origin strains that may result in a pandemic. Protection induced by evolutionarily stable influenza antigens is associated with viral clearance mediated by broadly reactive cytotoxic CD8+ $\mathrm{T}$ cells, reducing the severity of clinical disease (36). Candidate universal influenza vaccine targets include the nucleoprotein (NP), matrix proteins (M1 and M2), and the RNA-directed RNA polymerase catalytic subunit (PB1). Individual plasmids encoding NP (37) and M2 (38) have each been reported to decrease viral load and enhance survival against lethal heterologous challenge viruses in $\mathrm{BALB} / \mathrm{c}$ mice. Combined immunisation with matrix protein, $\mathrm{NP}$, and PB1 plasmids has been reported to induce protection against heterologous challenge in mice (39), pigs (40), ferrets (41), and macaques (42). Chimeric protein antigens designed to increase the breadth of host responses can be delivered by DNA vaccines. Plasmid-encoded fusion proteins of H1N1 HA and the conserved M2-ectodomain improved the cross-reactivity of antibody responses to drifted $\mathrm{H} 1 \mathrm{~N} 1$ viruses compared to a plasmid encoding HA alone in mice (43).

Attempts to create HA-based universal influenza vaccines have targeted the conserved stem region of the HA protein (31). Mice vaccinated with plasmids encoding a PR8 "headless HA" antigen developed serum antibody responses to a greater range of influenza viruses than wild-type HA DNA-vaccinated animals (44). The expression of consensus HA sequences has also increased the cross-reactivity of antibody responses (45-47). Chen et al. (48) constructed a plasmid encoding a consensus H5 HA generated from $467 \mathrm{HA}$ sequences, which induced protection against a wide spectrum of lethal H5N1 reassortant challenge viruses in mice. Broadly reactive responses have also been induced using polyvalent formulations similar to currently available trivalent and quadrivalent IIVs (26). Huber et al. (49) generated crossreactive antibodies against multiple $\mathrm{H} 3$ drift variants in mice by vaccinating with three different $\mathrm{H} 3$-expressing plasmids. Rao et al. (50) achieved similar success against several variant H5N1 viruses in chickens using vaccines containing up to 10 different H5 HA plasmids.

Efficient antigen expression in situ is a key factor for DNA vaccine effectiveness which can be modulated by altering the antigen coding sequence. Encoding antigens using codons optimised for expressing within the host species is a commonly used strategy to enhance influenza DNA vaccine expression (51-53). Jiang et al. (54) used a lethal H5N1 challenge model in chickens to compare the protective efficacy of DNA vaccines encoding either the wildtype HA or HA codon-optimised for chickens. Chickens receiving the codon-optimised HA plasmid demonstrated up to fourfold increases in antibody titre compared to animals inoculated with wild-type HA plasmids, resulting in greater survival rates during viral challenge.

DNA vaccine antigen design can direct the post-translational trafficking of expressed proteins to influence the development of host immunity. The human tissue plasminogen activator leader sequence promotes high levels of protein secretion and has improved antibody responses to an H5 HA DNA vaccine in rabbits (55). Grodeland et al. (29) encoded DNA vaccine antigens consisting of H1 HA linked to MHC class II-targeting units which enhanced its delivery to antigen-presenting cells (APCs). Ferrets and pigs vaccinated with plasmids expressing the targeted $\mathrm{H} 1$ fusion protein generated significant antibody titres, whereas $\mathrm{H} 1$ DNA alone failed to cause seroconversion. A similar DNA vaccine strategy expressing APC-targeted $\mathrm{H} 7$ fusion proteins was found to improve anti-HA serum antibody and cytotoxic T cell responses to highly pathogenic avian influenza (56).

\section{DNA VACCINE DELIVERY PLATFORMS}

For influenza DNA vaccines, the route of administration is critical to vaccine effectiveness as it dictates the cell types that will be transfected. DNA vaccines were initially tested in the murine model using intramuscular injection of naked plasmids to produce antigens in passively transfected myocytes (muscle cells) (57). This method relies on the influx of leucocytes following local inflammation to expose the immune system to DNA vaccine antigens (58). Outside of the murine model, effective intramuscular administration of plasmids depends on adjuvants and delivery systems to achieve sufficient immunogenicity (59). More recently, cutaneous delivery has become a highly desirable route for DNA vaccines, as the epidermis is abundant in Langerhans cells, which can efficiently transport and present DNA vaccine-encoded antigens in the lymph node (58).

Alternative delivery devices have been developed to improve upon traditional needle and syringe inoculation for parenteral administration. In small animal models, the gene gun induces immune responses successfully with low doses of DNA by delivering gas-propelled plasmid-coated gold microparticles directly into epidermal cells $(60,61)$. Human clinical trials of influenza DNA vaccines have successfully employed the Biojector system (iHealthNet, GA, USA), which uses pressurised $\mathrm{CO}_{2}$ to transport a liquid inoculum to the intradermal or intramuscular layer (62-64). Recently, the development of patches composed of micron-length needles has enabled the dermal delivery of lyophilised DNA vaccine (65-67). HA DNA vaccination in mice 
using dry-coated microneedle patches were reported to induce antibody titres and $\mathrm{T}$ cell responses up to five times higher than an equivalent intramuscular dose (68).

Parenteral gene delivery has been further enhanced by electroporation, which temporarily increases the permeability of local cell membranes with electrical pulses (69). Its early use alongside intramuscular delivery required highly invasive electrodes associated with excessive inflammation and the production of lesions (70). Updated devices such as the CELLECTRA system (Inovio, PA, USA) can target the dermal and subcutaneous layers and are optimised to be minimally invasive for clinical use (71). Electroporation has been reported to enable influenza DNA vaccines to generate robust antibody titres and $\mathrm{T}$ cell responses in guinea pigs (72), swine (73), and macaques $(47,74)$.

The mucosa is an appealing site of inoculation for influenza vaccines as it is easily accessible and is the clinical site of entry for influenza viruses (75). Existing mucosal influenza vaccines such as FluMist (MedImmune, MD, USA) mediate protection through local mucosal inflammation and the production of secretory IgA $(34,76)$. The enrichment of dendritic cells and $\mathrm{M}$ cells at mucosal surfaces is ideal for the immune presentation of DNA vaccine antigens $(77,78)$. However, successful mucosal delivery of plasmids in large animal models requires specialised adjuvants or highly optimised delivery systems $(79,80)$. Torrieri-Dramard et al. (81) reported that an intranasal HA DNA vaccine failed to elicit detectable IgA titres unless the plasmid was complexed with a polyethylenimine nanocarrier. To induce detectable seroconversion in sheep, Rajapaksa et al. (82) used a novel acoustic nebuliser to produce aerosols of an optimal size to deliver HA plasmids to deep lung tissue.

\section{ADJUVANTS}

The co-administration of adjuvants with influenza DNA vaccines is a common strategy to elicit adequate levels of protection in vivo. The mechanisms of action for licensed conventional adjuvants include the formation of antigen depot at the inoculation site, the activation of inflammatory pathways, and the recruitment of APCs (83).

The goal of adjuvant design is to increase the immune response to vaccine antigens, a critical hurdle in the DNA vaccine field. Mineral salts such as alum are widely used in human vaccines and have resulted in up to fivefold increase in HA DNA vaccine-induced antibody titres (84). Cytokine expression vectors exploit host signalling pathways to heighten immune stimulation (85). IL-6 is an important inflammatory mediator involved in B cell stimulation and the recruitment of leucocytes $(86,87)$. Co-administration of an IL-6-expressing plasmid in HA DNAvaccinated mice has been reported to reduce the duration of influenza illness (88). Lee et al. (60) reported that only $50 \%$ of HA and NP DNA-vaccinated mice survived a lethal homologous challenge, whereas mice receiving the additional IL-6-expressing plasmid were fully protected. The cytokine activity of high mobility group box 1 protein has been shown to increase the survival of mice vaccinated with NP DNA in a homologous viral challenge, and has been found to enhance antibody production induced by HA DNA vaccines by twofold (89). Cytokine adjuvants have also demonstrated effectiveness in large animal models such as macaques, where the use of adjuvant plasmids encoding GM-CSF, a potent immune cell proliferation and differentiation factor, resulted in up to fivefold increases in the serum antibody titre compared to a HA DNA vaccine delivered alone (90).

Adjuvant compounds developed as delivery reagents aim to improve the transfection efficiency of DNA vaccine plasmids. The efficiency of the cellular uptake of DNA vaccines is determined by cell membrane permeability and the susceptibility of foreign DNA to host enzymes. It is estimated that only $1 \%$ of a naked plasmid inoculation is able to reach the nuclei of target cells for protein expression-most plasmids remain in the extracellular space to be cleared by host processes (91). Synthetic nanocarriers form structures that protect DNA from host enzymes and facilitate its entry through the cell membrane lipid bilayer (85). Cationic lipids form vesicles known as liposomes, which interact electrostatically with negatively charged DNA to form lipoplexes that efficiently enter host cells through endocytosis (92). Vaxfectin (Vical, San Diego) is a cationic lipid-based system that has boosted influenza DNA vaccine immunogenicity in numerous large animal models (93-95). Other nanoparticle-forming polymers have been reported to enhance influenza DNA vaccine formulation including poly(lactic-co-glycolic) acid $(96,97)$, chitosan (98), and polyethylenimine (81).

\section{PRIME-BOOST STRATEGIES}

The administration of novel vaccine types including adenovirus vectors $(99,100)$, subviral particles (101), and recombinant protein antigens (102) in combination with conventional influenza vaccines has been reported to enhance seroconversion and antibody cross-reactivity. Wang et al. (103) demonstrated that a primary HA DNA vaccine followed by a seasonal trivalent inactivated vaccine (TIV) boost induced significantly higher antibody titres compared to two doses of either DNA vaccine or TIV in rabbits. Similar results have reported using DNA vaccines to prime LAIV in ferrets (104) and recombinant HA-protein vaccine in chickens (105). However, human trials applying this strategy against circulating seasonal influenza failed to significantly improve seroconversion compared to TIV alone $(106,107)$.

Despite this, studies have indicated that DNA vaccines may have a clinical application in pandemic settings. Chang et al. (108) demonstrated that mice which had been pre-exposed to $\mathrm{H} 1 \mathrm{~N} 1$ were significantly protected from lethal $\mathrm{H} 5 \mathrm{~N} 1$ challenge after DNA vaccination with $\mathrm{H} 5 \mathrm{~N} 1 \mathrm{NP}$ - and M1-expressing plasmids. Given the commonality of H1N1 exposure amongst the public, this suggests DNA vaccines could be rapidly deployed to protect a large susceptible population against H5N1 outbreaks. During the 2009 pandemic, a Phase 1 human clinical trial was conducted using an $\mathrm{A}(\mathrm{H} 1 \mathrm{~N} 1)$ pdm09 DNA vaccine produced 2 months before the licensed monovalent inactivated vaccine (MIV) (64). Seroconversion was observed in $30 \%$ of recipients after three doses of DNA vaccine delivered by Biojector, and the response rate rose to $72 \%$ after a booster dose of MIV. Similar human trials of DNA prime-MIV boost vaccines against H5N1 (109) and H7N9 (110) have reported significant improvements in antibody responses compared to MIV alone, indicating that DNA vaccines 
can effectively prime the immune system against viruses where there is low pre-existing immunity in the population. These recent developments indicate the potential for further research into combined DNA vaccine/IIV strategies as viable control measures against novel influenza outbreaks.

\section{FUTURE PROSPECTS}

After two decades of research, DNA vaccine technology is gaining maturity-several veterinary DNA vaccines are currently licensed for West Nile virus and melanoma (111), and significantly, the first commercial DNA vaccine against $\mathrm{H} 5 \mathrm{~N} 1$ in chickens has recently been conditionally approved by the USDA (112). In addition, ongoing large animal trials of DNA vaccines against other diseases such as against $\operatorname{HIV}(6,113,114)$, hepatitis $(115,116)$, and Zika virus $(117,118)$ offer valuable insights that can be applied to influenza DNA vaccine design. Promising approaches have arisen from the numerous studies evaluating different DNA vaccine formulations and delivery systems, but a strategy that consistently elicits protection against influenza in large animal models has not yet emerged. Successful plasmid

\section{REFERENCES}

1. WHO. Influenza (Seasonal) - Fact Sheet. Geneva: World Health Organisation Media Centre (2018). Available from: http://www.who.int/mediacentre/ factsheets/fs211/en/ (Accessed: April 17, 2018).

2. Sullivan SG, Chilver MB, Carville KS, Deng YM, Grant KA, Higgins G, et al. Low interim influenza vaccine effectiveness, Australia, 1 May to 24 September 2017. Euro Surveill (2017) 22(43):17-00707. doi:10.2807/1560-7917.ES.2017. 22.43.17-00707

3. Flannery B, Chung JR, Belongia EA, Mclean HQ, Gaglani M, Murthy K, et al. Interim estimates of 2017-18 seasonal influenza vaccine effectiveness United States, February 2018. MMWR Morb Mortal Wkly Rep (2018) 67: 180-5. doi:10.15585/mmwr.mm6706a2

4. Dos Santos G, Neumeier E, Bekkat-Berkani R. Influenza: can we cope better with the unpredictable? Hum Vaccin Immunother (2016) 12:699-708. doi:10.1080/21645515.2015.1086047

5. Bruffaerts N, Huygen K, Romano M. DNA vaccines against tuberculosis. Expert Opin Biol Ther (2014) 14:1801-13. doi:10.1517/14712598.2014.951630

6. Mann JF, Mckay PF, Fiserova A, Klein K, Cope A, Rogers P, et al. Enhanced immunogenicity of an HIV-1 DNA vaccine delivered with electroporation via combined intramuscular and intradermal routes. J Virol (2014) 88: 6959-69. doi:10.1128/JVI.00183-14

7. Yang B, Jeang J, Yang A, Wu TC, Hung C-F. DNA vaccine for cancer immunotherapy. Hum Vaccin Immunother (2014) 10:3153-64. doi:10.4161/2164551 5.2014 .980686

8. Rimmelzwaan GF, McElhaney JE. Correlates of protection: novel generations of influenza vaccines. Vaccine (2008) 26:D41-4. doi:10.1016/j.vaccine. 2008.07.043

9. Stachyra A, Gora-Sochacka A, Sirko A. DNA vaccines against influenza. Acta Biochim Pol (2014) 61:515-22.

10. Williams JA. Vector design for improved DNA vaccine efficacy, safety and production. Vaccines (Basel) (2013) 1:225-49. doi:10.3390/vaccines1030225

11. Xenopoulos A, Pattnaik P. Production and purification of plasmid DNA vaccines: is there scope for further innovation? Expert Rev Vaccines (2014) 13:1537-51. doi:10.1586/14760584.2014.968556

12. Gerdts V, Wilson HL, Meurens F, Van Drunen Littel-Van Den Hurk S, Wilson D, Walker S, et al. Large animal models for vaccine development and testing. ILAR J (2015) 56:53-62. doi:10.1093/ilar/ilv009

13. Porter KR, Raviprakash K. DNA vaccine delivery and improved immunogenicity. Curr Issues Mol Biol (2017) 22:129-38. doi:10.21775/cimb. 022.129 delivery and the use of appropriate adjuvants remain key challenges that need to be addressed before influenza DNA vaccines become effective for human use.

\section{AUTHOR CONTRIBUTIONS}

All authors listed have made a substantial, direct, and intellectual contribution to the work and approved it for publication.

\section{ACKNOWLEDGMENTS}

We would like to thank Paulina Koszalka for editing and critiquing early drafts of this review.

\section{FUNDING}

The Melbourne WHO Collaborating Centre for Reference and Research on Influenza is supported by the Australian Government Department of Health. LI and LL were supported by NHMRC development grant \#1112870.

14. van der Laan JW, Herberts C, Lambkin-Williams R, Boyers A, Mann AJ, Oxford J. Animal models in influenza vaccine testing. Expert Rev Vaccines (2008) 7:783. doi:10.1586/14760584.7.6.783

15. Bodewes R, Rimmelzwaan GF, Osterhaus ADME. Animal models for the preclinical evaluation of candidate influenza vaccines. Expert Rev Vaccines (2010) 9:59-72. doi:10.1586/erv.09.148

16. Munster VJ, De Wit E, Van Den Brand JMA, Herfst S, Schrauwen EJA, Bestebroer TM, et al. Pathogenesis and transmission of Swine-Origin 2009 A(H1N1) influenza virus in ferrets. Science (2009) 325:481-3. doi:10.1126/ science. 1177127

17. Belser JA, Katz JM, Tumpey TM. The ferret as a model organism to study influenza A virus infection. Dis Model Mech (2011) 4:575-9. doi:10.1242/ dmm.007823

18. Rimmelzwaan GF, Katz JM. Immune responses to infection with $\mathrm{H} 5 \mathrm{~N} 1$ influenza virus. Virus Res (2013) 178:44-52. doi:10.1016/j.virusres.2013. 05.011

19. Grunwald T, Ulbert S. Improvement of DNA vaccination by adjuvants and sophisticated delivery devices: vaccine-platforms for the battle against infectious diseases. Clin Exp Vaccine Res (2015) 4:1-10. doi:10.7774/ cevr.2015.4.1.1

20. Li L, Petrovsky N. Molecular mechanisms for enhanced DNA vaccine immunogenicity. Expert Rev Vaccines (2016) 15:313-29. doi:10.1586/14760584.2016. 1124762

21. Wong S-S, Webby RJ. Traditional and new influenza vaccines. Clin Microbiol $\operatorname{Rev}$ (2013) 26:476-92. doi:10.1128/CMR.00097-12

22. Schultz-Cherry S, Jones JC. Influenza vaccines: the good, the bad, and the eggs. Adv Virus Res (2010) 77:63-84. doi:10.1016/B978-0-12-385034-8. 00003-X

23. Kempe A, Daley MF, Stokley S, Crane LA, Beaty BL, Barrow J, et al. Impact of a severe influenza vaccine shortage on primary care practice. Am J Prev Med (2007) 33:486-91. doi:10.1016/j.amepre.2007.07.038

24. Uscher-Pines L, Barnett DJ, Sapsin JW, Bishai DM, Balicer RD. A systematic analysis of influenza vaccine shortage policies. Public Health (2008) 122:183-91. doi:10.1016/j.puhe.2007.06.005

25. Tewawong N, Prachayangprecha S, Vichiwattana P, Korkong S, Klinfueng S, Vongpunsawad $\mathrm{S}$, et al. Assessing antigenic drift of seasonal influenza $\mathrm{A}(\mathrm{H} 3 \mathrm{~N} 2)$ and $\mathrm{A}(\mathrm{H} 1 \mathrm{~N} 1) \mathrm{pdm} 09$ viruses. PLoS One (2015) 10:e139958. doi:10.1371/journal.pone.0139958

26. Zimmerman RK, Nowalk MP, Chung J, Jackson ML, Jackson LA, Petrie JG, et al. 2014-2015 influenza vaccine effectiveness in the United States by vaccine type. Clin Infect Dis (2016) 63:1564-73. doi:10.1093/cid/ciw635 
27. Parker L, Wharton SA, Martin SR, Cross K, Lin Y, Liu Y, et al. Effects of egg-adaptation on receptor-binding and antigenic properties of recent influenza A (H3N2) vaccine viruses. J Gen Virol (2016) 97:1333-44. doi:10.1099/ jgv.0.000457

28. Leitner WW, Ying H, Restifo NP. DNA and RNA-based vaccines: principles, progress and prospects. Vaccine (1999) 18:765-77. doi:10.1016/ S0264-410X(99)00271-6

29. Grodeland G, Fredriksen AB, Løset GÅ, Vikse E, Fugger L, Bogen B. Antigen targeting to human HLA class II molecules increases efficacy of DNA vaccination. J Immunol (2016) 197:3575-85. doi:10.4049/jimmunol.1600893

30. Rush C, Mitchell T, Garside P. Efficient priming of CD4+ and CD8+ T cells by DNA vaccination depends on appropriate targeting of sufficient levels of immunologically relevant antigen to appropriate processing pathways. J Immunol (2002) 169:4951. doi:10.4049/jimmunol.169.9.4951

31. Wiersma LCM, Rimmelzwaan GF, De Vries RD. Developing universal influenza vaccines: hitting the nail, not just on the head. Vaccines (Basel) (2015) 3: 239-62. doi:10.3390/vaccines3020239

32. Robinson HL, Hunt LA, Webster RG. Protection against a lethal influenza virus challenge by immunization with a haemagglutinin-expressing plasmid DNA. Vaccine (1993) 11:957-60. doi:10.1016/0264-410X(93)90385-B

33. Robinson HL, Boyle CA, Feltquate DM, Morin MJ, Santoro JC, Webster RG. DNA immunization for influenza virus: studies using hemagglutinin- and nucleoprotein-expressing DNAs. J Infect Dis (1997) 176:S50-5. doi:10.1086/ 514176

34. Barría MI, Garrido JL, Stein C, Scher E, Ge Y, Engel SM, et al. Localized mucosal response to intranasal live attenuated influenza vaccine in adults. J Infect Dis (2013) 207:115-24. doi:10.1093/infdis/jis641

35. Sridhar S, Begom S, Bermingham A, Hoschler K, Adamson W, Carman W, et al. Cellular immune correlates of protection against symptomatic pandemic influenza. Nat Med (2013) 19:1305. doi:10.1038/nm.3350

36. Berlanda Scorza F, Tsvetnitsky V, Donnelly JJ. Universal influenza vaccines: shifting to better vaccines. Vaccine (2016) 34:2926-33. doi:10.1016/j.vaccine. 2016.03.085

37. Ulmer JB, Donnelly JJ, Parker SE, Rhodes GH, Felgner PL, Dwarki VJ, et al. Heterologous protection against influenza by injection of DNA encoding a viral protein. Science (1993) 259:1745-9. doi:10.1126/science.8456302

38. Tompkins SM, Zhao ZS, Lo CY, Misplon JA, Liu T, Ye Z, et al. Matrix protein 2 vaccination and protection against influenza viruses, including subtype H5N1. Emerg Infect Dis (2007) 13:426-35. doi:10.3201/eid1303.061125

39. Wang W, Li R, Deng Y, Lu N, Chen H, Meng X, et al. Protective efficacy of the conserved NP, PB1, and M1 proteins as immunogens in DNA- and vaccinia virus-based universal influenza A virus vaccines in mice. Clin Vaccine Immunol (2015) 22:618-30. doi:10.1128/CVI.00091-15

40. Bragstad K, Vinner L, Hansen MS, Nielsen J, Fomsgaard A. A polyvalent influenza A DNA vaccine induces heterologous immunity and protects pigs against pandemic $\mathrm{A}(\mathrm{H} 1 \mathrm{~N} 1) \mathrm{pdm} 09$ virus infection. Vaccine (2013) 31:2281-8. doi:10.1016/j.vaccine.2013.02.061

41. Price GE, Soboleski MR, Lo C-Y, Misplon JA, Pappas C, Houser KV, et al. Vaccination focusing immunity on conserved antigens protects mice and ferrets against virulent $\mathrm{H} 1 \mathrm{~N} 1$ and H5N1 influenza A viruses. Vaccine (2009) 27:6512-21. doi:10.1016/j.vaccine.2009.08.053

42. Koday MT, Leonard JA, Munson P, Forero A, Koday M, Bratt DL, et al. Multigenic DNA vaccine induces protective cross-reactive $\mathrm{T}$ cell responses against heterologous influenza virus in nonhuman primates. PLoS One (2017) 12:e0189780. doi:10.1371/journal.pone.0189780

43. Park KS, Seo YB, Lee JY, Im SJ, Seo SH, Song MS, et al. Complete protection against a $\mathrm{H} 5 \mathrm{~N} 2$ avian influenza virus by a DNA vaccine expressing a fusion protein of H1N1 HA and M2e. Vaccine (2011) 29:5481-7. doi:10.1016/j. vaccine.2011.05.062

44. Steel J, Lowen AC, Wang TT, Yondola M, Gao Q, Haye K, et al. Influenza virus vaccine based on the conserved hemagglutinin stalk domain. MBio (2010) 1(1):e00018-10. doi:10.1128/mBio.00018-10

45. Wang B, Yu H, Yang FR, Huang M, Ma JH, Tong GZ. Protective efficacy of a broadly cross-reactive swine influenza DNA vaccine encoding M2e, cytotoxic T lymphocyte epitope and consensus H3 hemagglutinin. Virol J (2012) 9:127. doi:10.1186/1743-422X-9-127

46. Choi EJ, Lee HS, Noh JY, Song JY, Cheong HJ, Shin OS, et al. Humoral and cellular immunogenicity induced by avian influenza A (H7N9) DNA vaccine in mice. Infect Chemother (2017) 49:117-22. doi:10.3947/ic.2017.49.2.117
47. Yan J, Morrow MP, Chu JS, Racine T, Reed CC, Khan AS, et al. Broad crossprotective anti-hemagglutination responses elicited by influenza microconsensus DNA vaccine. Vaccine (2018) 36(22):3079-89. doi:10.1016/j. vaccine.2017.09.086

48. Chen M-W, Cheng T-JR, Huang Y, Jan J-T, Ma S-H, Yu AL, et al. A consensushemagglutinin-based DNA vaccine that protects mice against divergent H5N1 influenza viruses. Proc Natl Acad Sci USA (2008) 105:13538-43. doi:10.1073/pnas.0806901105

49. Huber VC, Thomas PG, Mccullers JA. A multi-valent vaccine approach that elicits broad immunity within an influenza subtype. Vaccine (2009) 27: 1192-200. doi:10.1016/j.vaccine.2008.12.023

50. Rao S, Kong WP, Wei CJ, Yang ZY, Nason M, Styles D, et al. Multivalent HA DNA vaccination protects against highly pathogenic H5N1 avian influenza infection in chickens and mice. PLoS One (2008) 3:e2432. doi:10.1371/ journal.pone.0002432

51. Wang S, Taaffe J, Parker C, Solorzano A, Cao H, Garcia-Sastre A, et al. Hemagglutinin (HA) proteins from $\mathrm{H} 1$ and $\mathrm{H} 3$ serotypes of influenza $\mathrm{A}$ viruses require different antigen designs for the induction of optimal protective antibody responses as studied by codon-optimized HA DNA vaccines. J Virol (2006) 80:11628-37. doi:10.1128/JVI.01065-06

52. Tenbusch M, Grunwald T, Niezold T, Bonsmann MSG, Hannaman D, Norley S, et al. Codon-optimization of the hemagglutinin gene from the novel swine origin $\mathrm{H} 1 \mathrm{~N} 1$ influenza virus has differential effects on CD4+ T-cell responses and immune effector mechanisms following DNA electroporation in mice. Vaccine (2010) 28:3273-7. doi:10.1016/j.vaccine.2010.02.090

53. Stachyra A, Redkiewicz P, Kosson P, Protasiuk A, Gora-Sochacka A, Kudla G, et al. Codon optimization of antigen coding sequences improves the immune potential of DNA vaccines against avian influenza virus $\mathrm{H} 5 \mathrm{~N} 1$ in mice and chickens. Virol J (2016) 13:143. doi:10.1186/s12985-016-0599-y

54. Jiang Y, Yu K, Zhang H, Zhang P, Li C, Tian G, et al. Enhanced protective efficacy of $\mathrm{H} 5$ subtype avian influenza DNA vaccine with codon optimized HA gene in a pCAGGS plasmid vector. Antiviral Res (2007) 75:234-41. doi:10.1016/j.antiviral.2007.03.009

55. Wang S, Hackett A, Jia N, Zhang C, Zhang L, Parker C, et al. Polyvalent DNA vaccines expressing $\mathrm{HA}$ antigens of $\mathrm{H} 5 \mathrm{~N} 1$ influenza viruses with an optimized leader sequence elicit cross-protective antibody responses. PLoS One (2011) 6:e28757. doi:10.1371/journal.pone.0028757

56. Andersen TK, Zhou F, Cox R, Bogen B, Grødeland G. A DNA vaccine that targets hemagglutinin to antigen presenting cells protects mice against $\mathrm{H} 7$ influenza. J Virol (2017) 91(23):e01340-17. doi:10.1128/JVI.01340-17

57. Wolff JA, Malone RW, Williams P, Chong W, Acsadi G, Jani A, et al. Direct gene transfer into mouse muscle in vivo. Science (1990) 247:1465-8. doi:10.1126/ science. 1690918

58. Combadiere B, Liard C. Transcutaneous and intradermal vaccination. Hum Vaccin (2011) 7:811-27. doi:10.4161/hv.7.8.16274

59. Widera G, Austin M, Rabussay D, Goldbeck C, Barnett SW, Chen M, et al. Increased DNA vaccine delivery and immunogenicity by electroporation in vivo. J Immunol (2000) 164:4635-40. doi:10.4049/jimmunol.164. 9.4635

60. Lee SW, Youn JW, Seong BL, Sung YC. IL-6 induces long-term protective immunity against a lethal challenge of influenza virus. Vaccine (1999) 17:490-6. doi:10.1016/S0264-410X(98)00223-0

61. Yager EJ, Stagnar C, Gopalakrishnan R, Fuller JT, Fuller DH. Optimizing particle-mediated epidermal delivery of an influenza DNA vaccine in ferrets. Methods Mol Biol (2013) 940:223-37. doi:10.1007/978-1-62703-110-3_19

62. Ledgerwood JE, Hu Z, Gordon IJ, Yamshchikov G, Enama ME, Plummer S, et al. Influenza virus h5 DNA vaccination is immunogenic by intramuscular and intradermal routes in humans. Clin Vaccine Immunol (2012) 19:1792-7. doi:10.1128/CVI.05663-11

63. Graham BS, Enama ME, Nason MC, Gordon IJ, Peel SA, Ledgerwood JE, et al. DNA vaccine delivered by a needle-free injection device improves potency of priming for antibody and CD8+ T-cell responses after rAd5 boost in a randomized clinical trial. PLoS One (2013) 8:e59340. doi:10.1371/ journal.pone.0059340

64. Crank MC, Gordon IJ, Yamshchikov GV, Sitar S, Hu Z, Enama ME, et al. Phase 1 study of pandemic H1 DNA vaccine in healthy adults. PLoS One (2015) 10:e0123969. doi:10.1371/journal.pone.0123969

65. Raphael AP, Prow TW, Crichton ML, Chen X, Fernando GJ, Kendall MA. Targeted, needle-free vaccinations in skin using multilayered, densely-packed 
dissolving microprojection arrays. Small (2010) 6:1785-93. doi:10.1002/ smll.201000326

66. Kim YC, Song JM, Lipatov AS, Choi SO, Lee JW, Donis RO, et al. Increased immunogenicity of avian influenza DNA vaccine delivered to the skin using a microneedle patch. Eur J Pharm Biopharm (2012) 81:239-47. doi:10.1016/j. ejpb.2012.03.010

67. Fernando GJ, Zhang J, Ng HI, Haigh OL, Yukiko SR, Kendall MA. Influenza nucleoprotein DNA vaccination by a skin targeted, dry coated, densely packed microprojection array (Nanopatch) induces potent antibody and CD8(+) T cell responses. J Control Release (2016) 237:35-41. doi:10.1016/j. jconrel.2016.06.045

68. Song J-M, Kim Y-C, Eunju O, Compans RW, Prausnitz MR, Kang S-M. DNA vaccination in the skin using microneedles improves protection against influenza. Mol Ther (2012) 20:1472-80. doi:10.1038/mt.2012.69

69. Smith TRF, Schultheis K, Kiosses WB, Amante DH, Mendoza JM, Stone JC, et al. DNA vaccination strategy targets epidermal dendritic cells, initiating their migration and induction of a host immune response. Mol Ther Methods Clin Dev (2014) 1:14054. doi:10.1038/mtm.2014.54

70. Hartikka J, Sukhu L, Buchner C, Hazard D, Bozoukova V, Margalith M, et al. Electroporation-facilitated delivery of plasmid DNA in skeletal muscle: plasmid dependence of muscle damage and effect of poloxamer 188. Mol Ther (2001) 4:407-15. doi:10.1006/mthe.2001.0483

71. Diehl MC, Lee JC, Daniels SE, Tebas P, Khan AS, Giffear M, et al. Tolerability of intramuscular and intradermal delivery by CELLECTRA $\left({ }^{\circledR}\right)$ adaptive constant current electroporation device in healthy volunteers. Hum Vaccin Immunother (2013) 9:2246-52. doi:10.4161/hv.24702

72. Schultheis K, Schaefer H, Yung BS, Oh J, Muthumani K, Humeau L, et al. Characterization of guinea pig $\mathrm{T}$ cell responses elicited after EP-assisted delivery of DNA vaccines to the skin. Vaccine (2017) 35:61-70. doi:10.1016/j. vaccine.2016.11.052

73. Borggren M, Nielsen J, Bragstad K, Karlsson I, Krog JS, Williams JA, et al. Vector optimization and needle-free intradermal application of a broadly protective polyvalent influenza A DNA vaccine for pigs and humans. Hum Vaccin Immunother (2015) 11:1983-90. doi:10.1080/21645515.2015. 1011987

74. Laddy DJ, Yan J, Khan AS, Andersen H, Cohn A, Greenhouse J, et al. Electroporation of synthetic DNA antigens offers protection in nonhuman primates challenged with highly pathogenic avian influenza virus. J Virol (2009) 83:4624-30. doi:10.1128/JVI.02335-08

75. Zanin M, Baviskar P, Webster R, Webby R. The interaction between respiratory pathogens and mucus. Cell Host Microbe (2016) 19:159-68. doi:10.1016/j.chom.2016.01.001

76. Gould VMW, Francis JN, Anderson KJ, Georges B, Cope AV, Tregoning JS. Nasal IgA provides protection against human influenza challenge in volunteers with low serum influenza antibody titre. Front Microbiol (2017) 8:900. doi:10.3389/fmicb.2017.00900

77. Zaman M, Chandrudu S, Toth I. Strategies for intranasal delivery of vaccines. Drug Deliv Transl Res (2013) 3:100-9. doi:10.1007/s13346-012-0085-Z

78. Loh L, Wang Z, Sant S, Koutsakos M, Jegaskanda S, Corbett AJ, et al. Human mucosal-associated invariant $\mathrm{T}$ cells contribute to antiviral influenza immunity via IL-18-dependent activation. Proc Natl Acad Sci U S A (2016) 113: 10133-8. doi:10.1073/pnas.1610750113

79. Xu Y, Yuen PW, Lam JK. Intranasal DNA vaccine for protection against respiratory infectious diseases: the delivery perspectives. Pharmaceutics (2014) 6:378-415. doi:10.3390/pharmaceutics6030378

80. Savelkoul HF, Ferro VA, Strioga MM, Schijns VE. Choice and design of adjuvants for parenteral and mucosal vaccines. Vaccines (Basel) (2015) 3:148-71. doi:10.3390/vaccines3010148

81. Torrieri-Dramard L, Lambrecht B, Ferreira HL, Van Den Berg T, Klatzmann D, Bellier B. Intranasal DNA vaccination induces potent mucosal and systemic immune responses and cross-protective immunity against influenza viruses. Mol Ther (2011) 19:602-11. doi:10.1038/mt.2010.222

82. Rajapaksa AE, Ho JJ, Qi A, Bischof R, Nguyen T-H, Tate M, et al. Effective pulmonary delivery of an aerosolized plasmid DNA vaccine via surface acoustic wave nebulization. Respir Res (2014) 15:60-60. doi:10.1186/14659921-15-60

83. He P, Zou Y, Hu Z. Advances in aluminum hydroxide-based adjuvant research and its mechanism. Hum Vaccin Immunother (2015) 11:477-88. doi:10.1080/21645515.2014.1004026
84. Ulmer JB, Dewitt CM, Chastain M, Friedman A, Donnelly JJ, Mcclements WL, et al. Enhancement of DNA vaccine potency using conventional aluminum adjuvants. Vaccine (1999) 18:18-28. doi:10.1016/S0264-410X(99)00151-6

85. Li L, Petrovsky N. Molecular adjuvants for DNA vaccines. Curr Issues Mol Biol (2017) 22:17-40. doi:10.21775/cimb.022.017

86. Silver JS, Hunter CA. gp130 at the nexus of inflammation, autoimmunity, and cancer. J Leukoc Biol (2010) 88:1145-56. doi:10.1189/jlb.0410217

87. Rose-John S. IL-6 trans-signaling via the soluble IL-6 receptor: importance for the pro-inflammatory activities of IL-6. Int J Biol Sci (2012) 8:1237-47. doi:10.7150/ijbs.4989

88. Larsen DL, Dybdahl-Sissoko N, Mcgregor MW, Drape R, Neumann V, Swain WF, et al. Coadministration of DNA encoding interleukin-6 and hemagglutinin confers protection from influenza virus challenge in mice. J Virol (1998) 72:1704-8.

89. Fagone P, Shedlock DJ, Bao H, Kawalekar OU, Yan J, Gupta D, et al. Molecular adjuvant HMGB1 enhances anti-influenza immunity during DNA vaccination. Gene Ther (2011) 18:1070-7. doi:10.1038/gt.2011.59

90. Loudon PT, Yager EJ, Lynch DT, Narendran A, Stagnar C, Franchini AM, et al. GM-CSF increases mucosal and systemic immunogenicity of an H1N1 influenza DNA vaccine administered into the epidermis of non-human primates. PLoS One (2010) 5:e11021. doi:10.1371/journal.pone.0011021

91. Babiuk LA, Pontarollo R, Babiuk S, Loehr B, Van Drunen Littel-Van Den Hurk S. Induction of immune responses by DNA vaccines in large animals. Vaccine (2003) 21:649-58. doi:10.1016/S0264-410X(02)00574-1

92. Hoekstra D, Rejman J, Wasungu L, Shi F, Zuhorn I. Gene delivery by cationic lipids: in and out of an endosome. Biochem Soc Trans (2007) 35:68-71. doi:10.1042/BST0350068

93. Jimenez GS, Planchon R, Wei Q, Rusalov D, Geall A, Enas J, et al. Vaxfectinformulated influenza DNA vaccines encoding NP and M2 viral proteins protect mice against lethal viral challenge. Hum Vaccin (2007) 3:157-64. doi:10.4161/hv.3.5.4175

94. Lalor PA, Webby RJ, Morrow J, Rusalov D, Kaslow DC, Rolland A, et al. Plasmid DNA-based vaccines protect mice and ferrets against lethal challenge with A/Vietnam/1203/04 (H5N1) influenza virus. J Infect Dis (2008) 197:1643-52. doi:10.1086/588431

95. Smith LR, Wloch MK, Ye M, Reyes LR, Boutsaboualoy S, Dunne CE, et al. Phase 1 clinical trials of the safety and immunogenicity of adjuvanted plasmid DNA vaccines encoding influenza A virus $\mathrm{H} 5$ hemagglutinin. Vaccine (2010) 28:2565-72. doi:10.1016/j.vaccine.2010.01.029

96. Wang G, Pan L, Zhang Y, Wang Y, Zhang Z, Lu J, et al. Intranasal delivery of cationic PLGA nano/microparticles-loaded FMDV DNA vaccine encoding IL-6 elicited protective immunity against FMDV challenge. PLoS One (2011) 6:e27605. doi:10.1371/journal.pone.0027605

97. Seok H, Noh JY, Lee DY, Kim SJ, Song CS, Kim YC. Effective humoral immune response from a H1N1 DNA vaccine delivered to the skin by microneedles coated with PLGA-based cationic nanoparticles. J Control Release (2017) 265:66-74. doi:10.1016/j.jconrel.2017.04.027

98. Sawaengsak C, Mori Y, Yamanishi K, Srimanote P, Chaicumpa W, Mitrevej A, et al. Intranasal chitosan-DNA vaccines that protect across influenza virus subtypes. Int J Pharm (2014) 473:113-25. doi:10.1016/j.ijpharm.2014.07.005

99. Khurana S, Coyle EM, Manischewitz J, King LR, Ishioka G, Alexander J, et al. Oral priming with replicating adenovirus serotype 4 followed by subunit $\mathrm{H} 5 \mathrm{~N} 1$ vaccine boost promotes antibody affinity maturation and expands H5N1 cross-clade neutralization. PLoS One (2015) 10:e115476. doi:10.1371/journal.pone.0115476

100. Wu Y, Yang D, Xu B, Liang W, Sui J, Chen Y, et al. Immune efficacy of an adenoviral vector-based swine influenza vaccine against antigenically distinct H1N1 strains in mice. Antiviral Res (2017) 147:29-36. doi:10.1016/j. antiviral.2017.09.009

101. Elaish M, Ngunjiri JM, Ali A, Xia M, Ibrahim M, Jang H, et al. Supplementation of inactivated influenza vaccine with norovirus $P$ particle-M2e chimeric vaccine enhances protection against heterologous virus challenge in chickens. PLoS One (2017) 12:e0171174. doi:10.1371/journal.pone.0171174

102. Zhu W, Pewin W, Wang C, Luo Y, Gonzalez GX, Mohan T, et al. A boosting skin vaccination with dissolving microneedle patch encapsulating M2e vaccine broadens the protective efficacy of conventional influenza vaccines. J Control Release (2017) 261:1-9. doi:10.1016/j.jconrel.2017.06.017

103. Wang S, Parker C, Taaffe J, Solórzano A, García-Sastre A, Lu S. Heterologous HA DNA vaccine prime - inactivated influenza vaccine boost is more 
effective than using DNA or inactivated vaccine alone in eliciting antibody responses against $\mathrm{H} 1$ or $\mathrm{H} 3$ serotype influenza viruses. Vaccine (2008) 26:3626-33. doi:10.1016/j.vaccine.2008.04.073

104. Suguitan AL Jr, Cheng X, Wang W, Wang S, Jin H, Lu S. Influenza H5 hemagglutinin DNA primes the antibody response elicited by the live attenuated influenza A/Vietnam/1203/2004 vaccine in ferrets. PLoS One (2011) 6: e21942. doi:10.1371/journal.pone.0021942

105. Stachyra A, Pietrzak M, Macioła A, Protasiuk A, Olszewska M, Śmietanka K, et al. A prime/boost vaccination with HA DNA and Pichia-produced HA protein elicits a strong humoral response in chickens against H5N1. Virus Res (2017) 232:41-7. doi:10.1016/j.virusres.2017.01.025

106. Ledgerwood JE, Bellamy AR, Belshe R, Bernstein DI, Edupuganti S, Patel SM, et al. DNA priming for seasonal influenza vaccine: a phase $1 \mathrm{~b}$ double-blind randomized clinical trial. PLoS One (2015) 10:e0125914. doi:10.1371/journal.pone. 0125914

107. Ledgerwood JE, Hu Z, Costner P, Yamshchikov G, Enama ME, Plummer S, et al. Phase I clinical evaluation of seasonal influenza hemagglutinin (HA) DNA vaccine prime followed by trivalent influenza inactivated vaccine (IIV3) boost. Contemp Clin Trials (2015) 44:112-8. doi:10.1016/j.cct.2015.08.006

108. Chang H, Huang C, Wu J, Fang F, Zhang W, Wang F, et al. A single dose of DNA vaccine based on conserved $\mathrm{H} 5 \mathrm{~N} 1$ subtype proteins provides protection against lethal $\mathrm{H} 5 \mathrm{~N} 1$ challenge in mice pre-exposed to H1N1 influenza virus. Virol J (2010) 7:197-197. doi:10.1186/1743-422X-7-197

109. Ledgerwood JE, Zephir K, Hu Z, Wei CJ, Chang L, Enama ME, et al. Primeboost interval matters: a randomized phase 1 study to identify the minimum interval necessary to observe the H5 DNA influenza vaccine priming effect. J Infect Dis (2013) 208:418-22. doi:10.1093/infdis/jit180

110. DeZure AD, Coates EE, Hu Z, Yamshchikov GV, Zephir KL, Enama ME, et al. An avian influenza H7 DNA priming vaccine is safe and immunogenic in a randomized phase I clinical trial. NPJ Vaccines (2017) 2:15. doi:10.1038/ s41541-017-0016-6

111. Myhr AI. DNA vaccines: regulatory considerations and safety aspects. Curr Issues Mol Biol (2017) 22:79-88. doi:10.21775/cimb.022.079

112. AgriLabs. First DNA Vaccine Licensed for Chickens. PR Newswire: Cision (2017). Available: https://www.prnewswire.com/news-releases/first-dnavaccine-licensed-for-chickens-300554855.html (Accessed: January 14, 2018).
113. Takeda A, Igarashi H, Nakamura $H$, Kano M, Iida A, Hirata $T$, et al. Protective efficacy of an AIDS vaccine, a single DNA priming followed by a single booster with a recombinant replication-defective Sendai virus vector, in a macaque AIDS model. J Virol (2003) 77:9710-5. doi:10.1128/ JVI.77.17.9710-9715.2003

114. Yu S, Feng X, Shu T, Matano T, Hasegawa M, Wang X, et al. Potent specific immune responses induced by prime-boost-boost strategies based on DNA, adenovirus, and Sendai virus vectors expressing gag gene of Chinese HIV-1 subtype B. Vaccine (2008) 26:6124-31. doi:10.1016/j.vaccine.2008. 09.017

115. Grubor-Bauk B, Yu W, Wijesundara D, Gummow J, Garrod T, Brennan AJ, et al. Intradermal delivery of DNA encoding HCV NS3 and perforin elicits robust cell-mediated immunity in mice and pigs. Gene Ther (2016) 23:26-37. doi:10.1038/gt.2015.86

116. Lee H, Jeong M, Oh J, Cho Y, Shen X, Stone J, et al. Preclinical evaluation of multi antigenic HCV DNA vaccine for the prevention of hepatitis $C$ virus infection. Sci Rep (2017) 7:43531. doi:10.1038/srep43531

117. Gaudinski MR, Houser KV, Morabito KM, Hu Z, Yamshchikov G, Rothwell RS, et al. Safety, tolerability, and immunogenicity of two Zika virus DNA vaccine candidates in healthy adults: randomised, open-label, phase 1 clinical trials. Lancet (2017) 391:552-62. doi:10.1016/S0140-6736(17)33105-7

118. Tebas P, Roberts CC, Muthumani K, Reuschel EL, Kudchodkar SB, Zaidi FI, et al. Safety and immunogenicity of an anti-Zika virus DNA vaccine preliminary report. N Engl J Med (2017). doi:10.1056/NEJMoa 1708120

Conflict of Interest Statement: The authors declare that they have no commercial or financial relationships that could be construed as a potential conflict of interest.

Copyright $\odot 2018$ Lee, Izzard and Hurt. This is an open-access article distributed under the terms of the Creative Commons Attribution License (CC BY). The use, distribution or reproduction in other forums is permitted, provided the original author(s) and the copyright owner(s) are credited and that the original publication in this journal is cited, in accordance with accepted academic practice. No use, distribution or reproduction is permitted which does not comply with these terms. 